\title{
Decrease of Household Waste Incineration Risks in Waste Collection, Transportation and Landfilling
}

\author{
Natālija Cudečka-Purinaa ${ }^{1}$, Vladimirs Cudečkis ${ }^{2},{ }^{1}$ BA School of Business and Finance, ${ }^{2}$ Vides Centrs Ltd.
}

\begin{abstract}
Municipal waste management is an activity that decreases environmental hazard and impact on human health, on the other hand, it is still linked with possible technogenic risks during management processes. The paper is focused on the assessment of low potential risk with the high impact on technogenic safety - waste inflammation at different waste management stages. The paper performs an assessment of most common inflammation causes and offers a variety of activities to be undertaken to eliminate or decrease such risks. As one of the solutions in order to minimise possible inflammation risk, the authors advise improving sorting system so that the fractions that are exposed to inflammation are sorted out at the early stages and managed in the best possible way.
\end{abstract}

Keywords - Inflammation, risk assessment, waste management.

\section{INTRODUCTION}

Municipal solid waste management is a multidisciplinary activity that includes generation, source separation, storage, collection, transfer and transport, processing and recovery, and, last but not least, disposal [7]. Waste in general is a heterogeneous substance with different chemical composition and chemical reactions occurring while being accumulated or disposed, moreover, waste is considered to be a combustible matter. The paper analyses this matter at different stages of processing and disposal - in waste containers, in the vehicles, at waste sorting stations and on the landfill. Inflammation risk is present at all stages of waste management to a greater or lesser extent.

Waste inflammation can occur:

- In waste containers - this may lead to material harm from container demolishing, pollution of the container area with combustion waste, risk of inflammation of nearby buildings;

- In waste collection trucks - leading to material loss from fire, truck repair works, pollution of the fire-development area with combustion waste, material loss from possible road traffic accident [12];

- At waste sorting stations - leading to material loss from fire in the premises;

- In the sub-standard landfills (dumpsites) - leading to pollution of the air with combustion waste, emission of toxic matters and their distribution over a larger area.

In order to improve technogenic safety of waste management processes, the authors offer a risk assessment methodology to identify most exposed stages and provide a list of recommendations and activities that can decrease the possible risks.
The following table provides an insight into risks and their influence on the environment. Taking into account the potential effects caused by inflammation on the air, soil, groundwater and directly on human health, it is highly important to perform preliminary risk assessment and undertake activities ensuring maximal risk minimisation.

TABLE I

RISK ASSESSMENT

\begin{tabular}{|l|l|}
\hline Risk source & Risk description \\
\hline Waste container & $\begin{array}{l}\text { Inflammation in the waste container, mainly due } \\
\text { to inhabitant negligence, while throwing out a } \\
\text { matter that is on fire or smouldering (from } \\
\text { cigarette end to still warm ashes - especially in the } \\
\text { rural areas); }\end{array}$ \\
\hline $\begin{array}{l}\text { Waste collection } \\
\text { truck }\end{array}$ & $\begin{array}{l}\text { Inflammation of waste inside the waste collection } \\
\text { truck. In this case the truck has to be totally } \\
\text { emptied and only then the fire has to be } \\
\text { extinguished. }\end{array}$ \\
\hline $\begin{array}{l}\text { Sub-standard waste } \\
\text { landfill (dumpsite) }\end{array}$ & $\begin{array}{l}\text { Inflammation in the dumpsites mainly occurs due } \\
\text { to uncontrolled disposal and lack of isolating daily } \\
\text { layers/covers. }\end{array}$ \\
\hline
\end{tabular}

\section{METHODOLOGY OF RESEARCH}

This study is focused on the assessment of one of the main risks - inflammation of waste that may occur during waste treatment activities. After classification and assessment of the impacts at each of the treatment stages, the authors plan to evaluate risk level at each stage. The research is based on statistical data analysis. The authors have developed a risk value and factor matrix in order to visualise the potential impacts on the technogenic safety. This matrix has been developed based on expert method, i.e. expert risk gravity evaluation and application of this matrix to the assessed risk factors. The experts for this research have been chosen from the Latvian waste management industry that provided statistical data on inflammations within their organisations.

\section{RISK ASSESSMENT}

The risk of emission caused by landfill fire is assessed to be negligible as landfilling of organic waste without pretreatment is no longer permitted by the regulations of landfills [6], [10]. Simultaneously, waste inflammation in sub-standard landfills is quite an important issue, due to lack of control and fire prevention systems [2].

Below the authors perform risk assessment, based on expert risk evaluation - grading the likelihood of risk, i.e. how probable it is and how often a particular risk can occur as well as the extent of harm it can bring for each of the inflammation sources: 
TABLE II

RISK ASSESSMENT MATRIX

\begin{tabular}{|l|l|l|l|l|l|l|}
\hline & \multicolumn{6}{|l}{ Likelihood of harm } \\
\hline \multirow{4}{*}{} & Mark & 1 & 2 & 3 & 4 & 5 \\
\cline { 2 - 7 } & 1 & 1 & 2 & 3 & 4 & 5 \\
\cline { 2 - 7 } & 2 & 2 & 4 & 6 & 8 & 10 \\
\cline { 2 - 7 } & 3 & 3 & 6 & 9 & 12 & 15 \\
\cline { 2 - 7 } & 4 & 4 & 8 & 12 & 16 & 20 \\
\cline { 2 - 7 } & 5 & 5 & 10 & 15 & 20 & 25 \\
\hline \multirow{2}{*}{} & & & & & \\
\hline
\end{tabular}

Having performed risk assessment, the authors concluded that each type of risk has to be analysed taking into consideration different aspects for example, a significant difference of harm both to the environment and the risk source exists based on such aspects as: for waste containers dominating matter within inflammation is material, whether the container is made from plastic or metal; for waste collection trucks - whether the truck is operating in rural or urban area, etc. After distinguishing different risk aspects, the authors have assigned a score to each type of risk, based on their own expert opinion as well as on the expert evaluation from the industry and on statistical data.

Application of this matrix provides the following results:

\begin{tabular}{|l|l|l|l|}
\hline Source of inflammation & & Score & $\begin{array}{l}\text { Risk } \\
\text { ranking }\end{array}$ \\
\hline \multirow{2}{*}{ Waste container } & plastic & 8 & 3 \\
\cline { 2 - 4 } & metal & 6 & 3 \\
\hline \multirow{3}{*}{ Waste collection truck } & urban area & 20 & 1 \\
\cline { 2 - 4 } & rural area & 16 & 1 \\
\hline \multirow{3}{*}{ Waste sorting stations } & $\begin{array}{l}\text { short-term } \\
\text { storage }\end{array}$ & 12 & 2 \\
\cline { 2 - 4 } & $\begin{array}{l}\text { long-term } \\
\text { storage }\end{array}$ & 20 & 1 \\
\hline $\begin{array}{l}\text { Sub-standard waste } \\
\text { landfill (dumpsite) }\end{array}$ & & 25 & 1 \\
\hline
\end{tabular}

Risk ranking stands for:

1 - Urgent action to be taken; 2 - High priority; 3 - Medium priority.

Considering the abovementioned, it may be concluded that all the risks that may occur in the field of waste management and especially during waste collection, transportation and treatment stages are classified to be above medium priority. It is important to pay attention to both environmental and technogenic safety issues and entrepreneurial aspects, which might bring significant losses to the entity that suffers from any type of the abovementioned inflammation.

In order to assess the risks in a more detailed way, the authors evaluate each inflammation source on a stand-alone basis, performing a more in-depth analysis, distinguishing several aspects within each risk factor.

\section{Waste container}

It is vital to determine whether the waste container, which was affected by inflammation, is made from metal or plastic, as the second is more likely to be substituted when a metal container might be easily repaired. Possible inflammation of a building located by the container is another important hazard.

Waste management companies or a local authority that is in charge of waste management activities in a particular region often owns waste containers. Normally in Latvia waste containers are located on the streets by the buildings and only few are underground containers. It is waste container owner's responsibility to keep the container in an appropriate working condition and to monitor the necessity of repair works or substitution of containers.

Most common waste containers are produced from plastic or metal and have volumes of $240 \mathrm{~m}^{3}, 660 \mathrm{~m}^{3}$ and $1.1 \mathrm{~m}^{3}-$ for plastic containers and $1.1 \mathrm{~m}^{3}, 4 \mathrm{~m}^{3}, 6 \mathrm{~m}^{3}$ or $8 \mathrm{~m}^{3}$ - for metal containers. Smaller volume containers are used in the private house sector and bigger volume containers - by the blocks of flats.

On average, a waste container park is renewed once per 5 years. There are annual operation costs to cover waste container repair works or substitution of a container. A speciall material review board evaluates containers after fires.

Most common risks occurring are presented in the table below.

TABLE III

WASTE CONTAINER OPERATION RISKS

\begin{tabular}{|l|l|}
\hline Risk & Description \\
\hline Vandalism & $\begin{array}{l}\text { Mostly lowest harm like graffiti or breaking of } \\
\text { plastic or rubber elements }\end{array}$ \\
\hline Overload & $\begin{array}{l}\text { Exceeding the allowed weight of waste put into } \\
\text { one container that leads to container breakdown }\end{array}$ \\
\hline Theft & $\begin{array}{l}\text { Theft of the whole container or some of its parts } \\
\text { (i.e. lid or wheels), leading to explotation } \\
\text { limitation or impossibility }\end{array}$ \\
\hline Incineration & $\begin{array}{l}\text { Even a small fire occurring in a plastic container } \\
\text { may lead to its substitution }\end{array}$ \\
\hline
\end{tabular}

Waste collection truck

When analysing inflammation in waste container trucks, it is important to expand the analysis to the area where the accident occurs. In case of the urban area, it is almost impossible to empty the truck and extinguish the fire, which leads to major harm of the truck and repair cost escalation. In case the accident occurs in the rural area and the waste is unloaded, the truck driver can extinguish the fire. Thus this leads to other issues - the waste that has to be collected and loaded once again into the truck.

In case a fire occurs in a waste collection truck in the urban area, more often it will result to be economically sensitive.

In order to prevent a fire in a truck, it is advised to either equip the truck with internal fire detector system and/or to equip it with internal fire extinguishing system, so waste unloading might be prevented. In addition, it is advisable to omit high vehicle density routes as well as waste collection during rush hours.

\section{Waste sorting station}

Damage caused by inflammation in a waste sorting station is determined mostly depending on the following factors:

- Size of material storage - long-term or short-term and the volume of material stored there; 
- Fire safety equipment.

This type of inflammation is comparable to any warehouse fire, but most commonly all waste storage stations are equipped with fire safety systems so this type of inflammation risk can be minimised.

\section{Sub-standard waste landfill (dumpsite)}

One of most environementally hazardous inflammations is fire on a sub-standard landfill or a dumpsite. Landfill fires vary in scale from minor outbreaks on the surface to massive tyre conflagrations with the potential to cause environmental incidents exceeding, for instance, the impact of the Exxon Valdez oil spill in 1989. In human terms, the uncontrolled atmospheric emissions arising from these fires, which often continue for years, are potentially lethal with well-proven acute and chronic health impacts [5]. Environmental harm is determined by the fact that it is often very complicated to extinguish the fire, as burning process can be located deep in the dumpsite and stopping fire in one of its areas does not secure from inflammations in another area. Fires threaten the environment through toxic pollutants emitted into the air, water, and soil. Landfill emissions are the result of the decomposition of organic materials in the landfill (including yard waste, household waste, food waste, and paper) [1]. Landfill fires cause release of toxic organic compounds into atmosphere [9]. Sub-standard landfill fires as a major source of dioxins have also been reported [2], [8]. Another important aspect of dumpsite fire is its extinguishing possibility as often a sub-standard landfill lacks infrastructure, especially fire ponds, and taking into consideration that most commonly the landfills are located at a distance from urban areas, fire extinguishing process may result to be rather complex. The abovementioned leads to a conclusion that fire on a substandard landfill is a major threat to the environment and can cause more harm than it may be initially evaluated.

Sub-standard landfill fires occur frequently. In the USA there are around 8,300 fires a year [11] and in the United Kingdom around 280 to 300 a year [4].

\section{RISK MINIMISATION AND PREVENTION}

In order to minimise risks associated with waste collection, transportation and disposal processes, the authors have developed the following set of activities.

TABLE IV

RISK MINIMISATION AND PREVENTION MEASURES

\begin{tabular}{|c|c|c|c|}
\hline \multirow[t]{2}{*}{ Risk } & \multicolumn{3}{|l|}{ Activities } \\
\hline & Technical & Educational & Managerial \\
\hline $\begin{array}{l}\text { Waste } \\
\text { container }\end{array}$ & $\begin{array}{l}\text { Equipping } \\
\text { waste } \\
\text { containers with } \\
\text { fire } \\
\text { extinguishing } \\
\text { system }\end{array}$ & $\begin{array}{l}\text { Work with } \\
\text { society, } \\
\text { compilation of } \\
\text { the list of goods } \\
\text { prohibited for } \\
\text { disposal }\end{array}$ & $\begin{array}{l}\text { Locating container } \\
\text { at a safe distance } \\
\text { from buildings }\end{array}$ \\
\hline $\begin{array}{l}\text { Waste } \\
\text { collection } \\
\text { truck }\end{array}$ & $\begin{array}{l}\text { Equiping } \\
\text { vehicles with } \\
\text { fire safety } \\
\text { system }\end{array}$ & $\begin{array}{l}\text { Employee } \\
\text { training, how } \\
\text { to check the } \\
\text { containers } \\
\text { before emptying }\end{array}$ & $\begin{array}{l}\text { Developing } \\
\text { optimal routes } \\
\text { omitting waste } \\
\text { collection during } \\
\text { rush hours }\end{array}$ \\
\hline
\end{tabular}

\begin{tabular}{|l|l|l|l|}
\hline $\begin{array}{l}\text { Waste sorting } \\
\text { stations }\end{array}$ & $\begin{array}{l}\text { Equiping } \\
\text { stations with } \\
\text { fire safety } \\
\text { system }\end{array}$ & $\begin{array}{l}\text { Employee } \\
\text { training, plan } \\
\text { for fire } \\
\text { extinguishing }\end{array}$ & $\begin{array}{l}\text { Locating material, } \\
\text { prepared for } \\
\text { recycling at a safe } \\
\text { distance from } \\
\text { incoming waste } \\
\text { flow }\end{array}$ \\
\hline $\begin{array}{l}\text { Sub-standard } \\
\text { waste landfill } \\
\text { (dumpsite) }\end{array}$ & $\begin{array}{l}\text { Establishing a } \\
\text { firewater bassin } \\
\text { on a landfill } \\
\text { territory* }\end{array}$ & $\begin{array}{l}\text { Work with } \\
\text { society, } \\
\text { application of } \\
\text { fine system for } \\
\text { disposal of } \\
\text { waste in sub- } \\
\text { standard } \\
\text { landfills. }\end{array}$ & $\begin{array}{l}\text { Application of } \\
\text { daily covers and } \\
\text { monitoring of } \\
\text { waste management } \\
\text { on site* }\end{array}$ \\
\hline
\end{tabular}

* - in accordance with the EU requirements, all the sub-standard landfills in Latvia have to be already closed and recultivated. The authors provide preventive technical actions for the countries where such landfills still exist.

Landfill fire treatment:

External fire:

- excavation

- excavate and douse (known as 'overhaul' in the USA)

Internal fire:

- burying

- inert gas injection, using nitrogen or carbon dioxide;

- cryogenic (ground freezing)

- water-based techniques including water injection

- foam-based techniques [4].

All the above mentioned leads to a conclusion that significant precaution actions are to be taken in order to prevent risks that are associated with waste collection, transportation, sorting and landfilling.

\section{FINDINGS / RESULTS}

The research has revealed that most harm to the environment is caused by fire on sub-standard landfills, waste sorting stations with long-term storage and waste collection trucks, operating in urban areas. In order to minimise inflammation risks at different stages, different precaution methods are applied. For instance, it is possible to equip a waste container with fire extinguishing system. Such system might be linked with waste container filling alert system. It has to be noted that of course it has a direct impact on waste collection and management cost but, on the other hand, it significantly increases technogenic safety.

Another stage with the possibility of inflammation is while waste is being transported in a waste truck. In case of fire, two options exist - either the truck operator has to empty the cargo on the road way, which leads to contamination of air, groundwater and soil in the particular environment and may impact human health. The other option, depending on the equipment of waste collection truck, is accident prevention with the help of internal fire extinguishing system. It has to be noted that both options make waste unusable for sorting or production of secondary raw materials or RDF.

Last but not least stage where uncontrolled inflammations could occur is waste dumpsites or sub-standard landfills. This is explained with the fact that dumpsites are uncontrolled sites and waste there is exposed to all possible chemical processes. A landfill site, on the contrary, is a controlled area where 
waste after being transported is compacted and a daily and/or weekly cover is applied in order to isolate current volume from general waste volume with this decreasing possible chemical processes and inflammation. It has to be noted that with the closure and recultivation of sub-standard landfills (dumpsites) this risk has decreased significantly as landfills are much more controlled and have to comply with the EU developed Council Directive 1999/31/EC (substituted with Directive 2008/98/EC), which foresees strict control of incoming waste and application of both daily and weekly covers [3]. In order to decrease this type of risks, such dumpsites should be eliminated as a class and constant area monitoring should be performed in order to timely prevent their creation.

\section{CONCLUSION}

One of the main conclusions drawn by the authors based on the research and after they have developed risk assessment matrix and identified risk minimisation measures is that waste management is a process that not only purifies our environment, facilitates circular economy and promotes reduced impact raw-material use, it may also have a significant impact on technogenic safety if all possible risks are not neutralized or minimized promptly. A range of preventive actions are to be taken in order to decrease the possibility of risk. For example, both waste containers and waste collection vehicles are to be equipped with fire extinguishing systems. In order to decrease the volume of combustible waste arriving to the landfill and being disposed, it is recommended to: a) promote and increase the volume and quality of waste sorting; b) consider possibilities of RDF production (although not neglecting critical evaluation of its merchandising).

The authors note that this particular paper is mainly focused on waste container risk assessment, the authors provide results for other types of risks that will be assessed in depth in the next paper.

\section{REFERENCES}

[1] A. Rim-Rukeh, "An Assessment of the Contribution of Municipal Solid Waste Dump Sites Fire to Atmospheric Pollution Open Journal of Air Pollution," Open Journal of Air Pollution, 2014, vol. 3, pp. 53-60. http://dx.doi.org/10.4236/ojap.2014.33006

[2] J. Bogner, R. Pipatti, R. Hashimoto, C. Diaz, K. Mareckova, L. Diaz,

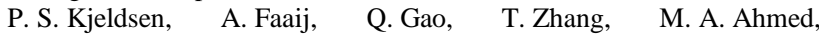
R. T. M. Sutamihardja, R. Gregory, "Mitigation of Global Greenhouse Gas Emissions from Waste: Conclusions and Strategies from the
Intergovernmental Panel on Climate Change (IPCC) Fourth Assessment Report," Working Group III (Mitigation), Waste Management Research, vol. 26, 2008, pp. 11-13. http://dx.doi.org/10.1177/0734242X07088433

[3] EU Waste Framework, "Directive 2008/98/EC on waste," Official Journal of the European Union.

[4] P. Foss-Smith, "Understanding landfill fires," Waste management world, 2010. [Online]. Available: http://www.waste-management-world.com/ articles/print/volume-11/issue-4/Features/understanding-landfill-fires.html. [Accessed: Sep. 21, 2014].

[5] ISWA - International Solid Waste Association, Waste and Climate Change, [Online]. Available: https://www.iswa.org/fileadmin/user_upload/ _temp_/WEB_ISWA_White_paper.pdf, Sep. 2010. [Accessed: Oct. 7, 2014].

[6] OECD, Addressing the Economics of Waste, OECD Publishin, 2004.

[7] E. C. Rada, M. Ragazzi, P. Fedrizzi, "Web-GIS oriented systems viability for municipal solid waste selective collection optimization in developed and transient economies," Waste Management, 2013, vol. 33, pp. 785-792. http://dx.doi.org/10.1016/j.wasman.2013.01.002

[8] O. Roots, B. Henkelmann, and K. W. Schramm, "Concentrations of Polychlorinated Dibenzo-p-Dioxins and Polychlorinated Dibenzofurans in Soil in the Vicinity of a Landfill," Chemosphere, 2004, vol. 57, pp. 337-342. http://dx.doi.org/10.1016/j.chemosphere.2004.06.012

[9] P. Ruokojarvi, J. Ruuskanen, and M. Ettala, "Landfill Fires and Emissions of Toxic Organic Compounds," Environmental Impact, Aftercare and Remediation of Landfills, CISA, Cagliari, 1997, vol. 4, pp. 151-154.

[10] C. Scheutz, P. Kjeldsen and E. Gentil, "Greenhouse gases, radiative forcing, global warming potential and waste management - an introduction," Waste Management and Research, 2009, vol. 27, no. 8, pp. 716-723. http://dx.doi.org/10.1177/0734242X09345599

[11] US Fire Administration, Fire in the United States 1992-2001, 13th ed., 2004, p. 197. [Online]. Available: http://www.usfa.fema.gov/downloads/ pdf/publications/fa-286.pdf [Accessed: Oct. 12, 2014].

[12] Z. Zsigraiova, V. Semiao and F. Beijoco, "Operation costs and pollutant emissions reduction by definition of new collection scheduling and optimization of MSW collection routes using GIS. The case study of Barreiro, Portugal," Waste Management, Apr. 2013, vol. 33, no. 4, pp. 793-806. http://dx.doi.org/10.1016/j.wasman.2012.11.015

Natālija Cudečka-Purina received the MBA degree from the University of Salford, Greater Manchester, United Kingdom, in 2011, and the degree of Master in Business Management from Riga International School of Economics and Business Administration in 201.

She is currently a Senior Expert with the Division of Environmental Quality and Waste Management of the Department of Environmental Protection of the Ministry of Environmental Protection and Regional Development.

She is a member of Waste Management Association of Latvia and International Solid Waste Association.

E-mail: natalija@vct.lv

Vladimirs Cudečkis received the $M g$. oec. degree from Riga Technical University in 2000 .

He is currently Chairman of the Board of "Vides centrs", Skolas iela 21, LV-1010, Riga, Latvia. Previously he worked at "L\&T" Ltd.

$\mathrm{He}$ is a member of Waste Management Association of Latvia, "Vides centrs" Ltd.

Address : "Vides centrs", Skolas iela 21, LV-1010, Riga, Latvia

E-mail: vmc@inbox.lv 